\title{
Conservation of sequence in the internal transcribed spacers and 5.8S ribosomal RNA among geographically separated isolates of parasitic scuticociliates (Ciliophora, Orchitophryidae)*
}

\author{
C. L. Goggin**, N. E. Murphy \\ Centre for Research on Introduced Marine Pests (CRIMP), CSIRO Marine Research, GPO Box 1538, Hobart Tasmania 7001, Australia
}

ABSTRACT: Nucleotide sequence from the internal transcribed spacers (ITS1 and ITS2) and the 5.8S gene from the ribosomal RNA gene cluster of isolates of the scuticociliate Orchitophrya stellarum from 4 asteroid hosts were compared. Surprisingly, these data (495 bp) were identical for $O$. stellarum isolated from the testes of Asterias amurensis from Japan; Pisaster ochraceus from British Columbia, Canada; Asterias rubens from The Netherlands; and Asterias vulgaris from Prince Edward Island, Canada. These sequence data were compared to those from 3 scuticociliates which parasitise crustaceans: Mesanophrys pugettensis, M. chesapeakensis and Anophryoides haemophila. No difference was found in this region between the nucleotide sequence of $M$. pugettensis and $M$. chesapeakensis. The sequence of Mesanophrys spp. differed by $9.2 \%$ in the ITS 1 and $4.7 \%$ in the ITS2 from that of $O$. stellarum. The sequence from the ITS1 (135 bp) and ITS2 (233 bp) of A. haemophila differed by 42.6 and $20.5 \%$ respectively from those of O. stellarum. Therefore, nucleotide sequence of the ITS regions in these scuticociliates is highly conserved.

KEY WORDS: Orchitophrya - Mesanophrys - Anophryoides . ITS · Scuticociliate

The taxonomy of scuticociliates is based primarily on oral structures and somatic kinetids. However, oral structures are plastic even within a class and are considered 'frail characters' to separate even subphyla (Greenwood et al. 1991). Somatic kinetids are arguably the most conservative of all ciliate structures and can provide insight into phylogenetic relationships (Lynn \& Small 1988) but are limited in their ability to discriminate close relatives. Molecular data can be used to sup-

\footnotetext{
- Nucleotide sequence data reported in this paper have been submitted to the GenBank database with the accession numbers AF107773, AF107774, AF107775, AF107776, AF107777, AF107778 and AF107779

•-E-mail: louise.goggin@marine.csiro.au
}

plement classical morphological taxonomy. In particular, the internal transcribed spacers (ITS1 and ITS2) in the ribosomal RNA (rRNA) gene cluster have been used to discriminate the alveolates which comprise the apicomplexans (Cai et al. 1992, Goggin 1994, Schlotterer et al. 1994, Homan et al. 1997), dinoflagellates (Hudson \& Adlard 1996) and ciliates (Diggles \& Adlard 1997). We investigated the utility of this region to discriminate orchitophryid scuticociliates which are geographically separated

In particular, we chose the parasitic scuticociliate Orchitophrya stellarum which was first described within the testes of the asteroid seastar Asterias rubens from France (Cépède 1907). The same species has since been recorded from the Pacific and Atlantic Oceans: from A. forbesi from Connecticut, USA (Burrows 1936), A. vulgaris from Prince Edward Island and Quebec, Canada (Smith 1936, Claereboudt \& Bouland 1994), Sclerasterias richardii from the Mediterranean Sea (Febvre et al. 1981), Pisaster ochraceus from British Columbia, Canada (Leighton et al. 1991), and A. amurensis from Japan (Byrne et al. 1997, Goggin \& Bouland 1997). Few of these isolates have been adequately described and, to our knowledge, none have been deposited in museums. Therefore, the specific identity of these ciliates remains uncertain.

To determine the variation in the ITS regions between orchitophryid scuticociliates, we compared 4 wild isolates of Orchitophrya stellarum from around the globe with 3 scuticociliates which parasitise crustaceans and were held in laboratory cultures.

Materials and methods. Testes infected with Orchitophrya stellarum were collected from 4 asteroid seastars from the Pacific and Atlantic oceans: Asterias rubens in April 1997 from Wemeldinge, Oosterschelde, The Netherlands ( $\mathrm{n}=4$ ); A. vulgaris in May 1997 from Murray River, Prince Edward Island, Canada $(\mathrm{n}=3)$; 
Pisaster ochraceus in May 1997 from Seymour Bay, Bowen Island, British Columbia, Canada ( $\mathrm{n}=3$ ); and A. amurensis in June 1996 from Usujiri, Hokkaido, Japan $(n=4)$. The infected testes were preserved in $100 \%$ ethanol.

Three scuticociliates kept in culture media (modified ATCC 1651 MA medium with the addition of $10 \%$ foetal bovine serum) since September 1995 were also collected: Anophryoides haemophila isolated from the lobster Homarus americanus; Mesanophrys chesapeakensis from the blue crab Callinectes sapidus; and $M$. pugettensis from the dungeness crab Cancer magister. These ciliates were kindly supplied by Dr R. J. Cawthorn, Atlantic Veterinary College, The University of Prince Edward Island, Canada. Cultures were centnifuged to concentrate the ciliates and the pellet was preserved in $100 \%$ ethanol.

Ethanol was removed and ciliates or tissue crushed in extraction buffer $(50 \mathrm{mM}$ Tris, pH $8.0,0.7 \mathrm{M} \mathrm{NaCl}$, $10 \mathrm{mM}$ EDTA, $1 \%$ hexadecyltrimethylammonium bromide, $0.1 \% 2$-mercaptoethanol) prior to incubation at $65^{\circ} \mathrm{C}$ for $1 \mathrm{~h}$ with $100 \mu \mathrm{g} \mathrm{ml}^{-1}$ proteinase-k added. DNA was extracted using phenol/chloroform, precipitated in ethanol and resuspended in double distilled water. A region of $r$ DNA was amplified from all isolates by polymerase chain reaction (PCR) in $50 \mu \mathrm{l}$ volumes using 20 ng DNA, $800 \mu \mathrm{m}$ dNTPs (Promega, Wisconsin, USA) and 20 pm each primer (Bresatec, Adelaide, Australia). A forward primer (SB2) located in the 3' region of the small subunit (SSU) rRNA gene and a reverse primer (ITS2.2) located at the $5^{\prime}$ region of the large subunit (LSU) gene were used in PCR (Goggin \& Newman 1996). Other PCR reagents were as supplied in a Perkin-Elmer kit (California, USA) and used in the following concentrations: 1.25 Units AmpliTaq Gold, $0.1 \mathrm{mM} \mathrm{MgCl}_{2}$ in buffer (5 mM Tris- $\mathrm{HCl}, 50 \mathrm{mM} \mathrm{KCl}, \mathrm{pH}=8.3$ ). PCR were run for 30 cycles of: $94^{\circ} \mathrm{C}$ for $60 \mathrm{~s}, 56^{\circ} \mathrm{C}$ for $30 \mathrm{~s}$ and $72^{\circ} \mathrm{C}$ for $90 \mathrm{~s}$ with a final cycle of $94^{\circ} \mathrm{C}$ for $60 \mathrm{~s}, 55^{\circ} \mathrm{C}$ for $30 \mathrm{~s}$ and $72^{\circ} \mathrm{C}$ for $7 \mathrm{~min}$. The amplified region comprised the $3^{\prime}$ region of the SSU gene, the ITS1, 5.8S gene, ITS2 and 5' region of the LSU gene and was approximately $750 \mathrm{bp}$ in all ciliates. DNA was purified using QiaQuick spin columns (QIAGEN Inc., Chatsworth) following the protocol recommended by the manufacturer. PCR products were sequenced using the same primers in a dye terminator sequencing reaction (Perkin-Elmer) and run on an acrylamide gel on an automated sequencer (ABI Prism 377 DNA sequencer). Sequences were collected from Orchitophrya stellarum isolated from 3 hosts at each site, 2 separate cultures of both Mesanophrys chesapeakensis and Anophryoides haemophila, and a single culture of $M$. pugettensis. Forward and reverse sequences were collected from all ciliate isolates

Results and discussion. Surprisingly, there were no differences between nucleotide sequence from the
ITS1 (140 bp), 5.8S (119 bp) and ITS2 (236 bp) rRNA of Orchitophrya stellarum isolated from Asterias amurensis, A. rubens, A. vulgaris and Pisaster ochraceus (Fig 1). The lack of variation was unexpected given the geographic and host spread of these isolates. Even more surprisingly, there were no differences between the ITS1 (139 bp) or the ITS2 (233 bp) of Mesanophrys pugettensis isolated from Cancer magister from the Pacific Ocean and $M$. chesapeakensis isolated from Callinectes sapidus from the Atlantic Ocean (Fig. 1). In contrast, the ITS sequence of the alga Cladophora albida from the Pacific Ocean differed by $21 \%$ from isolates in the Atlantic Ocean, while the sequence of isolates collected within either ocean were nearly identical (Bakker et al. 1992). Differences in the ITS regions have also been found between strains and species of ciliates. For example, the nucleotide sequence of 4 wild isolates of Cryptocaryon irritans differed by 0.6 to $4.1 \%$ in the ITS1 (Diggles \& Adlard 1997) while that of 2 species of Tetrahymena differed by $3 \%$ in ITS1 and 10\% in ITS2 (Engberg et al. 1990).

Furthermore, sequences from the ITS1 region of the ciliate Cryptocaryon irritans changed rapidly with passage in the laboratory and differed by $5.9 \%$ from the original isolate after approximately 1 yr (Diggles \& Adlard 1997). In our study, no difference was found between the sequence of the ITS regions of Mesanophrys pugettensis and $M$. chesapeakensis which were held in culture for about 18 mo (Fig. 1).

In some cases, little variation is found in ITS sequence between strains and species of protistans. For example, isolates of the protistan Perkinsus from Australia and Portugal had identical ITS1 sequences and $0.8 \%$ difference in ITS2 sequences (Goggin 1994). There were also no differences in the ITS1 or ITS2 of 12 isolates of Tritrichomonas foetus and $T$. suis (Felleisen 1997). Therefore, the ITS regions may be conserved in some species and strains. Indeed, it appears that the ITS regions of the scuticociliates sequenced here are conserved despite considerable geographic and reproductive isolation.

The nucleotide sequence from the ITS regions of Mesanophrys spp. are more similar to the consensus sequence of Orchitophrya stellarum than is that of Anophryoides haemophila. These sequences were aligned by eye to give a consensus sequence of $141 \mathrm{bp}$ for the ITS1, $119 \mathrm{bp}$ for the $5.8 \mathrm{~S}$ and $239 \mathrm{bp}$ for the ITS2 (Fig. 1). The consensus sequence of Mesanophrys spp. differed by $9.2 \%$ in the ITS1 ( 8 transversions, 2 transitions, 1 addition, 2 deletions) and $4.7 \%$ in the ITS2 (1 transversion, 7 transitions, 3 deletions) from that of O. stellarum (Table 1). The ITS1 of A. haemophila differed by $42.6 \%$ (45 transversions, 8 transitions, 1 addition, 6 deletions) and the ITS2 (233 bp) by $20.5 \%$ (21 transversions, 19 transitions, 3 additions, 6 dele- 


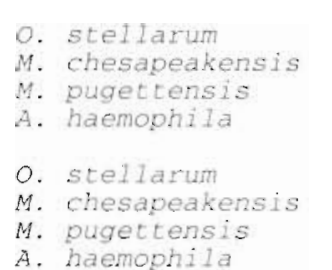

o. stellarum

M. chesapeakensis

M. pugettensis

A. haemophila

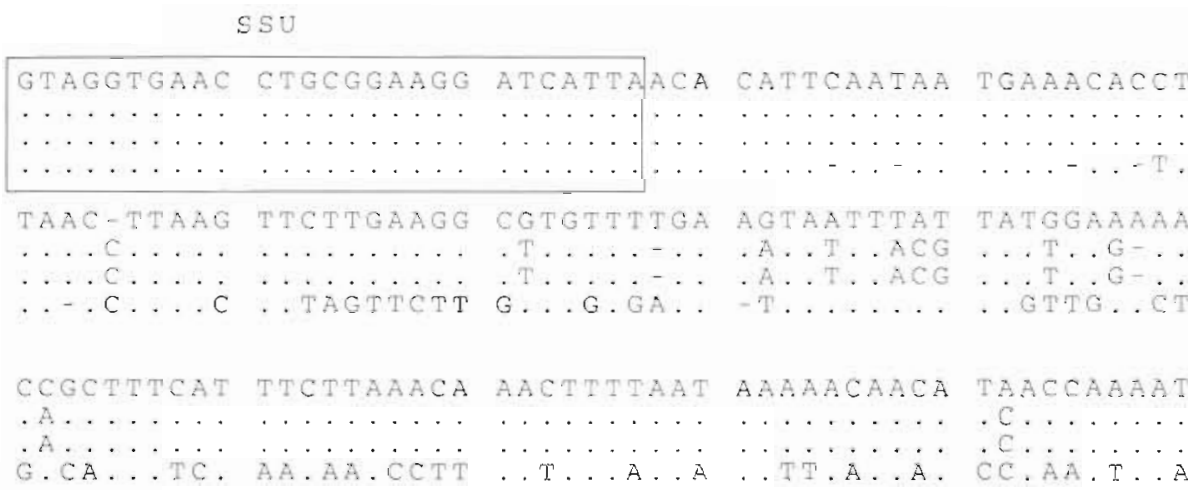

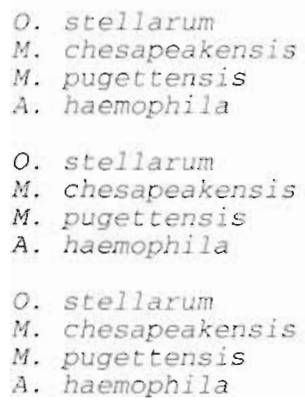

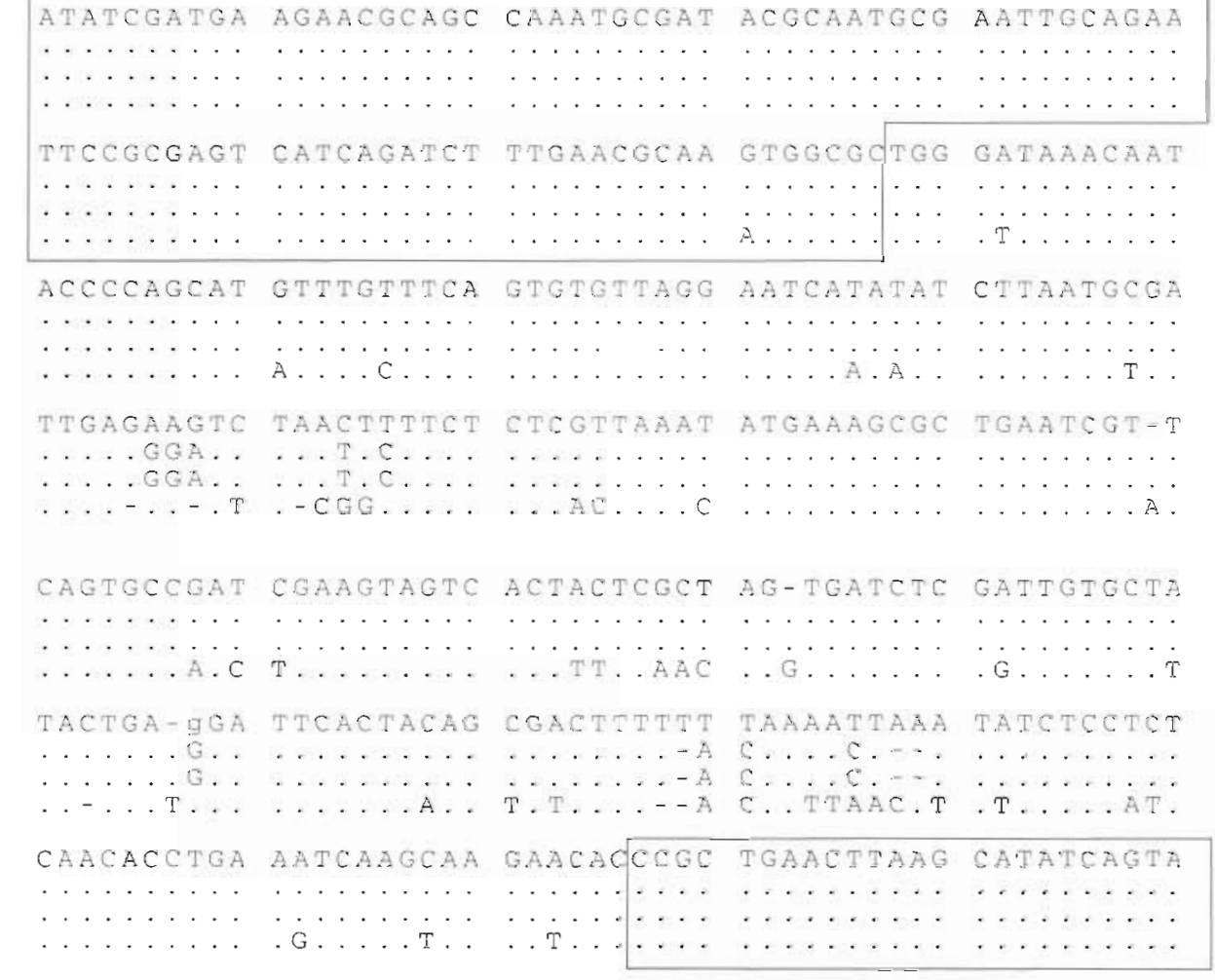

Fig. 1. Consensus nucleotide sequence data from the partial small subunit (SSU), internal transcribed spacer 1 (ITS1), 5.8S and ITS2 rRNA of the ciliate Orchitophrya stellarum, aligned with sequence from Mesanophrys chesapeakensis (AF107778), M. pugettensis (AF107777) and Anophryoides haemophila (AF107779). The data from O. stellarum are a consensus sequence of 4 geographically separate isolates from 4 seastar hosts: Asterias amurensis (from Japan, GenBank accession number AF107773), A. rubens (Netherlands, AF107776), A. vulgaris (Prince Edward Island, Canada, AF107774) and Pisaster ochraceus (British Columbia, Canada, AF107775). LSU: large subunit

tions) from that of $O$. stellarum (Table 1). Hudson \& Adlard (1996) found a 33.5 to $77.3 \%$ difference in partial ITS1 sequence between isolates of the dinoflagellate Hematodinium. Thus, this region varies much less between the scuticociliates sequenced here than some other alveolates.
The GC (guanine + cytosine) content of the ITS1 does not equal that of the ITS2 in Orchitophrya stellarum $(\operatorname{ITS} 1=24.3 \%$; ITS2 $=38.1 \%$ ), the consensus sequence from Mesanophrys spp. (ITS1 $=25.2 \%$, ITS2 $=39.4 \%$ ) or Anophryoides haemophila (ITS1 $=21.4 \%$, ITS2 $=36.4 \%$ ) which is unlike 19 other species of 
Table 1. Nucleotide sequence differences of the internal transcribed spacer 1 (ITS1), 5.8S and internal transcribed spacer 2 (ITS2) rRNA gene between the consensus sequence of 4 isolates of Orchitophrya stellarum (Os), the consensus sequence from Mesanophrys pugettensis and $M$. chesapeakensis (Mes) and Anophryoides haemophila (Ah)

\begin{tabular}{|c|c|c|c|c|c|c|c|c|c|c|}
\hline Species & $\begin{array}{l}\text { Position } \\
\text { differences }\end{array}$ & Os & $\begin{array}{l}\text { ITS1 } \\
\text { Mes }\end{array}$ & $A h$ & Os & $\begin{array}{l}5.8 \mathrm{~S} \\
\text { Mes }\end{array}$ & $A h$ & Os & $\begin{array}{l}\text { ITS } 2 \\
\text { Mes }\end{array}$ & Ah \\
\hline Orchitophrya stellarum & No. diff/total no. & $\begin{array}{c}0 \\
0 / 140\end{array}$ & $\begin{array}{c}9.2 \\
13 / 141\end{array}$ & $\begin{array}{c}42.6 \\
60 / 135\end{array}$ & $\begin{array}{c}0 \\
0 / 119\end{array}$ & $\begin{array}{c}0 \\
0 / 119\end{array}$ & $\begin{array}{c}1.7 \\
2 / 119\end{array}$ & $\begin{array}{c}0 \\
0 / 236\end{array}$ & $\begin{array}{c}4.7 \\
11 / 239\end{array}$ & $\begin{array}{c}20.5 \\
49 / 233\end{array}$ \\
\hline Mesanophrys spp. & $\begin{array}{l}\% \\
\text { No. diff/total no. }\end{array}$ & & $\begin{array}{c}0 \\
0 / 139\end{array}$ & $\begin{array}{c}46.1 \\
65 / 141\end{array}$ & & $\begin{array}{c}0 \\
0 / 119\end{array}$ & $\begin{array}{c}1.7 \\
2 / 119\end{array}$ & & $\begin{array}{c}0 \\
0 / 233\end{array}$ & $\begin{array}{c}21.0 \\
50 / 238\end{array}$ \\
\hline Anophryoides haemophila & $\begin{array}{l}\% \\
\text { No. diff/total no. }\end{array}$ & & & $\begin{array}{c}0 \\
0 / 135\end{array}$ & & & $\begin{array}{c}0 \\
0 / 119\end{array}$ & & & $\begin{array}{c}0 \\
0 / 233\end{array}$ \\
\hline
\end{tabular}

fungi, plants and animals (Torres et al. 1990). However, there is also an imbalance in the GC content of the ITS1 and ITS2 in the ciliate Tetrahymena thermophila (ITS1 $=29.8 \%$ GC content, ITS $2=43.3 \%$ ) (Engberg et al. 1990), the dinoflagellate Dictyostelium discoideum (ITS1 $=28 \%$, ITS2 $=43 \%$ ) (Ozaki et al. 1984), the kelp Alaria marginata (ITS1 $=52 \%$, ITS $2=$ $67 \%$ ) and many plants (Saunders \& Druehl 1993).

As expected, the 5.8S rRNA gene was highly conserved between these scuticociliates. The $5.8 \mathrm{~S}$ sequence of Mesanophrys spp. was identical to the consensus sequence from the 4 isolates of Orchitophrya stellarum (119 bp, $45.4 \%$ GC content); there was 1 transition and 1 transversion between these sequences and that of Anophryoides haemophila (Table 1).

In conclusion, data from ITS are highly conserved and unlikely to discriminate species or strains of orchitophryid scuticociliates but may be useful to discriminate genera in this group.

Acknowledgements. We thank the staff and students of the Usujiri Fisheries Laboratory, Japan, Mr B. Leighton (Simon Fraser University, Canada), Dr R. J. Cawthorn, Mr R. MacMillan, Ms B. Despres (Atlantic Veterinary College, Prince Edward Island, Canada), Dr C. De Ridder, Professor M. Jangoux and students and staff of the Department of Marine Biology, Université Libre de Bruxelles, for supplying infected seastars for this study. This work was supported by the Ian Potter Foundation, and the Bilateral Science and Technology Program of the Australian Department of Industry. Science and Tourism. This is publication CS08 of the Centre for Research on Introduced Marine Pests, CSIRO

\section{LITERATURE CITED}

Bakker FT, Olsen JL, Stam WT, van den Hoek C (1992) Nuclear ribosomal DNA internal transcribed spacer regions (ITS1 and ITS2) define discrete biogeographic groups in Cladophora albida (Chlorophyta). J Phycol 28: $839-845$

Burrows RB (1936) Further observations on parasitism in the starfish. Science 84:329

Byrne M, Cerra A, Nishigaki T, Hoshi M (1997) Infestation of the testes of the Japanese sea star Asterias amurensis by the ciliate Orchitophyra stellarum: a caution against the use of this ciliate for biological control. Dis Aquat Org 28: $235-239$

Cai J, Collins MD, McDonald V, Thompson DE (1992) PCR cloning and nucleotide sequence determination of the $18 \mathrm{~S}$ rRNA genes and internal transcribed spacer 1 of the protozoan parasites Cryptosporidium parvum and Cryptosporidium muris. Biochim Biophys Acta 1131:317-320

Cépède C (1907) La castration parasitaire des étoiles de mer males par un nouvel astome (Orchitophrya stellarum n. $\mathrm{g}$. n. sp.). C R Acad Sci (Paris) 145:1305-1306

Claereboudt MR, Bouland C (1994) The effect of parasitic castration by a ciliate on a population of Asterias vulgaris. $J$ Invertebr Pathol 63:172-177

Diggles BK, Adlard RD (1997) Intraspecific variation in Cryptocaryon irritans. J Eukaryot Microbiol 44:25-32

Engberg $J$, Nielson $H$, Lenaers $G$, Murayama O, Fujitani $H_{\text {, }}$ Higashinakagawa $\mathrm{T}(1990)$ Comparison of primary and secondary 26S rRNA structures in two Tetrahymena species: evidence for a strong evolutionary and structural constraint in expansion segments. J Mol Evol 30:514-521

Febvre M, Fredj-Reygrobellet D, Fredj G (1981) Reproduction sexuée d'une astérie fissipare Sclerasterias richardi (Perrier 1882). Int J Invertebr Reprod 3:193-208

Felleisen RSJ (1997) Comparative sequence analysis of 5.8S rRNA genes and internal transcribed spacer (ITS) regions of trichomonadid protozoa. Parasitology 115:111-119

Goggin CL (1994) Variation in the two internal transcribed spacers and 5.8S ribosomal RNA from five isolates of the marine parasite Perkinsus (Protista, Apicomplexa). Mol Biochem Parasitol 65:179-182

Goggin CL, Bouland C (1997) The ciliate Orchitophrya cf. stellarum and other parasites and commensals of the northern Pacific seastar Asterias amurensis from Japan. Int J Parasitol 27:1415-1418

Goggin CL, Newman LJ (1996) Use of molecular data to discriminate pseudocerotid turbellarians. J Helminthol 70 : $123-126$

Greenwood SJ, Schlegel M, Sogin ML, Lynn DH (1991) Phy logenetic relationships of Blepharisma americanum and Colpoda inflata within the phylum Ciliophora inferred from complete small subunit rRNA. gene sequences. J Protozool 38:1-6

Homan WL, Limper L, Verlaan $M$, Borst $A$, Vercammen $M$, van Knapen F (1997) Comparison of the internal transcribed spacer ITS1 from Toxoplasma gondii isolates and Neospora caninum. Parasitol Res 83:285-289

Hudson DA, Adlard RD (1996) Nucleotide sequence determination of the partial SSU rDNA gene and ITS1 region of Hematodinium cf. perezi and Hematodinium-like dino- 
flagellates. Dis Aquat Org 24:55-60

Leighton BJ, Boom JDG, Bouland C, Hartwick EB, Smith MJ (1991) Castration and mortality in Pisaster ochraceus parasitized by Orchitophrya stellarum (Ciliophora). Dis Aquat Org 10:71-73

Lynn DH, Small EB (1988) An update on the systematics of the phylum Ciliophora Doflein, 1901- the implications of kinetid diversity. Biosystems 21:317-322

Ozaki T, Hoshikawa Y, Iida Y, Iwabuchi M (1984) Sequence analysis of the transcribed and 5 ' non-transcribed regions of the ribosomal RNA gene in Dictyostelium discoideum. Nucleic Acids Res 12:4171-4184

Editorial responsibility: Larry Vaughan,

Dublin, Ireland
Saunders GW, Druehl LD (1993) Nucleotide sequences of the internal transcribed spacers and 5.8S rRNA genes from Alaria marginata and Postelsia palmaeformis (Phaeophyta: Laminariales). Mar Biol 115:347-352

Schlotterer C, Hauser M, von Haeseler A, Tautz D (1994) Comparative evolutionary analysis of rDNA ITS regions in Drosophila. Mol Biol Evol 11:513-522

Smith GFM (1936) A gonad parasite of the starfish. Science $\mathrm{XX:} 157$

Torres RA, Ganal M, Hemleben V (1990) GC balance in the internal transcribed spacers ITS1 and ITS2 of nuclear ribosomal genes. J Mol Evol 30:170-181

Submitted: March 13, 1999; Accepted: October 24, 1999 Proofs received from author(s): January 20, 2000 